\title{
THE HARMONISATION OF PRIVATE INTERNATIONAL LAW IN EUROPE: TAKING THE CHARACTER OUT OF FAMILY LAW?
}

\author{
MAEBH HARDING ${ }^{*}$
}

\begin{abstract}
A. InTRODUCTION
This article will examine the recent expansion of EU regulation of the private international law aspects of divorce and its consequences. The application of the regulatory framework made up of Brussels II bis, ${ }^{1}$ the Maintenance Regulation, ${ }^{2}$ Rome $\mathrm{II}^{3}$ and the proposed Rome $\mathrm{IV}^{4}$ to a typical divorce case will be investigated to see if this unwieldy system is coherent in application. The potential for divorce cases to be atomized into individual issues will be examined.

It will be asserted that the characterization used by this system best suits the decision making procedure under civil law traditions. The article will critically analyse how the characterization of issues as relating to divorce, maintenance or matrimonial property is likely to function in relation to the typical divorce under English and Welsh, Scottish and Irish law.

The problem areas of characterization will be examined and it will be shown that the difficulties encountered in making the common law systems fit the mould are actually substantive problems linked to the common law understanding of marriage as a publicly recognized and enforceable commitment. The tendency for common law jurisdictions to apply domestic law to cases with a foreign element is rooted in this vertical aspect of marriage.

It will be concluded that EU regulation of matrimonial breakdown based on three snapshots of the divorce process fails to properly consider the public dimension of marriage and the benefits of divorce as a process under one flexible and coherent domestic family law system.
\end{abstract}

\section{B. ThE COMMON LAW APPROACH TO DIVORCE AND ITS FINANCIAL CONSEQUENCES}

In any divorce, three stages can be identified. There is a declaration of divorce which represents a change in legal status. There is a determination of property ownership and there is a mechanism for financial compensation or support. It is the different relationships between these stages under the common law and civil law systems that must be examined to see if EU regulation in a private international law context may disrupt the application of coherent family law policy where there are international factors.

\footnotetext{
${ }^{*}$ PhD, Senior Lecturer in Law, University of Portsmouth.

${ }^{1}$ Regulation 2201/2003 EC [2003] OJ L 338/1.

${ }^{2}$ Regulation 4/2009 EC [2008] OJ L 7/1.

${ }^{3}$ Regulation 1259/2010 EU [2010] OJ L343/10.

${ }^{4}$ Green Paper on Conflicts of Laws in Matters Concerning Matrimonial Property Regimes, Including the Question of Jurisdiction and Mutual recognition of 17 July 2006; COM (2006) 400 final.
} 
The divorce process of the common law systems of Ireland and England has several distinctive aspects. Property rights and support obligations are dealt with together in a 'package solution'. A declaration of divorce can only be made by a court and can be withheld if certain basic obligations of support are not satisfied. The ability of the parties to privatise their future support obligations from the onset of marriage by a pre-nuptial agreement is very limited. The financial obligations of marriage can also continue beyond divorce.

In contrast under most civil law systems, property determination and questions of maintenance are two distinct concepts. Divorce is increasingly seen as a right and marital property agreements are usual and commonplace. ${ }^{5}$

\section{a) The link between the grant of divorce and satisfying financial obligations}

In Ireland, the grant of divorce itself is predicated on the financial obligations of marriage being satisfied. Divorce is only permitted under Article $41.3 .2^{\circ}$ of the Irish Constitution ${ }^{6}$ where "proper provision' as approved by the courts ${ }^{7}$ is made for spouses and children. ${ }^{8}$ This means that property and maintenance issues must be dealt with before the divorce is even granted and so the declaration of divorce cannot be separated from these determinations. The courts will always supervise the division of property and the allocation of maintenance.

In England and Wales, although financial affairs are commonly discussed and agreed before divorce is pronounced, the parties do not officially have to sort out their financial affairs until after the divorce is pronounced. In certain no fault divorce cases $^{9}$ the respondent can apply not to have the divorce granted unless the petitioner has made reasonable and fair financial provision. This defence is rarely used and seldom successful. ${ }^{10}$ This type of hardship clause is also found in many civil law systems. ${ }^{11}$ In reality there is no need for the English courts to check financial issues unless requested to do so by the parties through a consent order ${ }^{12}$ or on application for ancillary relief. ${ }^{13}$ However, unlike most civil systems, ${ }^{14}$ agreements between the parties on property division or support are not legally binding. The court always retains the right to determine the property and support obligations of marriage, although, unlike the Irish court, it does not always exercise this right. The English system thus sits on the fence, neither trusting the parties themselves to decide the financial consequences of marriage in a binding way nor requiring the courts to do so in every divorce case.

\footnotetext{
${ }^{5}$ A choice of different matrimonial property regimes has existed since 1804 under the French Civil Code and 1900 under the German Civil Code.

${ }^{6}$ Implemented by section 5 of the Family Law (Divorce) Act 1996.

${ }^{7}$ Section 20 of the Family Law (Divorce) Act 1996 sets out individual factors which must be taken into account by the Irish court before deciding to make any order of ancillary relief.

${ }^{8}$ See RG v GG [2005] IEHC 202.

${ }^{9}$ Section 10 of the Matrimonial Causes Act 1973.

${ }^{10}$ In petitions based solely on five year's separation, section 5 of the Matrimonial Causes Act 1973 permits the respondent to oppose its grant "on the ground that the dissolution of the marriage will result in grave financial or other hardship to him and that it would in all the circumstances be wrong to dissolve the marriage."

${ }^{11}$ See, eg France and Germany.

${ }^{12}$ Section 33A of the Matrimonial Causes Act 1973.

${ }^{13}$ Part II of the Matrimonial Causes Act 1973.

${ }^{14}$ See, eg German law where agreements on support ( $\S 1585 c$ German Civil Code) and property ( $\S 1408$ para. 1 German Civil Code) are binding and French law where agreements on property are binding (Art 1387 of the French Civil Code).
} 
In Scotland there is no need for the courts to determine property and support if not asked to do so, but in contrast to England, agreements between the parties are legally binding and so the financial obligations of marriage can be left entirely up to the autonomous decision of the spouses. ${ }^{15}$

\section{b) The place of private ordering}

While divorce must be pronounced by a court, in both England and Ireland, the details of the financial and property consequences of divorce can be determined by the parties, subject to different levels of court supervision.

In Ireland, the judge must ensure that 'proper provision' is met. In cases where this cannot be agreed the judge will decide what proper provision is. Any previous separation agreement must be taken into account by the court but is not determinative. ${ }^{16}$ In $R G v G G^{17}$ a couple made a separation agreement that claimed to represent proper provision and both parties relinquished their right to make a claim for ancillary relief in the future. Although this agreement had been turned into a court order upon a decree of judicial separation, Finlay Geoghegan J granted a lump sum payment and monthly periodical payments and a property adjustment order when granting the final divorce. She held that the court must exercise independent judgment to ascertain proper provision on the day of the divorce application. Parties cannot relinquish their right to ancillary relief. Agreements must be regarded and might have more evidentiary weight the closer they are made to divorce proceedings. Even if the parties settle on divorce, if a court is not satisfied as to proper provision, it may reexamine and amend previous agreements or orders, regardless of whether these were to the satisfaction of the parties or not.

In England and Wales, it is perfectly possible for the couple to sort out their own finances and never darken the door of the court for approval. The option of ancillary relief always remains and cannot be contracted away ${ }^{18}$ unless the couple turn their agreement into a consent order. In English law, all agreements as to the consequences of divorce can be modified by the courts. ${ }^{19}$ If the couple come to court for ancillary relief at a later date, the court will take their original agreement into account as a factual matter that it must give evidential weight to in deciding what would be fair in these circumstances.

The recent case of Radmacher $v$ Granatino ${ }^{20}$ has confirmed that pre-nuptial agreements should be given a similar weight to post- divorce settlement agreements when conducting this exercise. ${ }^{21}$ The Supreme Court held that pre-nuptial agreements would not be of any effect if they sought to prevent financial readjustment based on need or compensation or where it was necessary to provide for a child of the family. ${ }^{22}$ Thus an agreement providing for the non distribution of matrimonial property will be of no effect unless the court can provide for the needs of the spouses and children without redistributing property; a circumstance that will surely only occur in cases of the super rich. ${ }^{23}$

\footnotetext{
${ }^{15}$ Section 16(1)(b), Family Law (Scotland) Act 1985.

${ }^{16}$ Section 20 (3) Family Law (Divorce) Act 1996; MK v JK [2003] 1 IR 326.

${ }^{17}$ [2005] 2 IR 418.

18 Hyman v Hyman [1929] AC 601, HL. .

${ }^{19}$ Section 21(2)(c) Matrimonial Causes Act 1973.

20 [2010] UKSC 42.

${ }^{21}$ Ibid [62].

22 Ibid [82].

${ }^{23}$ In Radmacher the Supreme Court approved payments to the husband to the tune of nearly $f 5 \mathrm{M}$ to allow his children to have the same standard of living until they reached 25. Ibid [112].
} 
In Irish law, the place of pre-nuptial agreements has yet to be ascertained but the tendency is similar to that under the English system. They are not contrary to public policy per se but will only be taken into account when the result accords with proper provision. ${ }^{24}$

Scottish law allows binding pre-nuptial, post-nuptial and settlement agreements. ${ }^{25}$ An agreement may only be challenged, varied or set where it is found not to have been "fair and reasonable at the time it was entered into". ${ }^{26}$

Under Irish and English law, marriage still has a strong public element and is not viewed as private contract between individuals. ${ }^{27}$ While the courts no longer try to force the spouses to love honour and obey each other for life, they do police the financial obligations of marriage. Everyone is held to the same basic financial obligations and the autonomy of the parties has traditionally been of little importance. In contrast while marriage is also a public commitment under civil law systems, ${ }^{28}$ spouses have traditionally been able to privatise their property ownership. This is easier to do under a system where determination of property ownership and financial compensation serve different purposes as only one element has to be flexible for the courts to alleviate unfairness between the parties upon divorce.

\section{c) The overlap between property and maintenance}

In Ireland, England and Wales, determination of ownership of property and maintenance are conceptually intertwined. The obligation of the spouses to support each other is linked to property allocation at the end of the marriage. In a sense, the obligation is bought out by court orders based on need. A range of orders is available to the court including lump sum payments, periodical payments and property adjustment orders. ${ }^{29}$

In England and Wales, the court is able to look globally at the possible financial provision orders and property adjustment orders before deciding what orders should be in order to achieve 'fairness' between the parties. It must have regard to the welfare of any child of the family ${ }^{30}$ and it must also prioritise a clean break ${ }^{31}$ between the parties, but beyond this the legislation gives the courts almost total discretion. The courts have developed their own guiding principles in the absence of statutory policy. The latest, outlined in Miller v Miller; McFarlane $v$ McFarlane ${ }^{32}$ states that three elements of needs, compensation and sharing are to be separately considered and that the order of their determination will vary from case to case. This means that the court must ensure firstly that the reasonable needs of the couple, especially those relating to children, are satisfied. If there are any assets left over, the court should seek to compensate a spouse for any detriment suffered because of the marriage. Finally in 'big money' cases, where assets are left over, the court will seek to share

\footnotetext{
${ }^{24}$ See, Report of the Study Group on Pre-nuptial Agreements, (2007) http://www.inis.gov.ie/en/JELR/PrenupRpt.pdf/Files/PrenupRpt.pdf accessed on 2 February 2011.

${ }^{25}$ Minutes of Agreement are routinely used in many divorce cases.

${ }^{26}$ Section 16(1)(b) Family Law (Scotland) Act 1985.

${ }^{27}$ Article $41.3 .1^{\circ}$ of the Irish Constitution still requires the state to guard with special care the institution of Marriage, on which the Family is founded, and to protect it against attack.

${ }^{28}$ As reflected in the right to marry under Article 12 of the European Convention of Human Rights.

${ }^{29}$ England and Wales: Section 23 of the Matrimonial Causes Act 1973. Ireland: Section 13 of the Family Law (Divorce) Act 1996 allows for the making of periodical payments orders, secured periodical payments orders and lump sum orders; S. 9 of the Irish Family Law Act 1995 to "adjust" the property rights of spouses on the grant of a judicial separation by reference to a requirement for fairness.

${ }^{30}$ Section 25(1) Matrimonial Causes Act 1973.

31 Ibid section $25 \mathrm{~A}(1))$.

32 [2006] UKHL 24, [2006] 2 AC 618.
} 
the fruits of the marriage. This means that any leftover wealth generated during the marriage will be divided 50:50 unless there is clear reason to depart from this position. ${ }^{33}$

Because of the statutory preference for clean break, property readjustment and lump sum payments are preferred to ongoing periodic payments. Where there is not enough 'matrimonial property' to satisfy need, all the property can go into the pot. Thus the premarital property of a couple of scant means could be commandeered to ensure that their child's educational needs are catered for, or that a detriment suffered by a spouse is compensated. Only when the court is deciding how to share the 'fruits of the marriage' ${ }^{34}$ will the personal property of each spouse remain untouched. ${ }^{35}$ The potential for any agreement to ring-face assets will only be realised at the end of the marriage if there are enough assets to engage the third part of the Miller; McFarlane guidelines. Both property adjustment and financial orders are used to respond to current needs.

Ireland uses a similar package solution for financial provision and property adjustment. There is even less guidance in Irish statute law as to how the courts should use their ample discretion. What constitutes 'proper provision' is left entirely up to the discretion of the court. ${ }^{36}$ Section 20(1) of the Family Law (Divorce) Act 1996 states that "the court shall ensure that such provision as the court considers proper having regard to the circumstances...." and lists various factors which must be considered. In most cases the judges go through the list of factors and award relief based mainly on need. ${ }^{37} \operatorname{In} M B \vee B B^{38}$ the case by case nature of proper provision was confirmed.

Ireland does not have a statutory requirement of clean break, and it has been held that the courts are precluded from severing the financial obligations of one spouse to another. ${ }^{39}$ However, in 'big money' cases the Irish courts will use property adjustment orders and lump sum payments to encourage finality and discourage a return to court. ${ }^{40}$

In England and Ireland, there is no conceptual distinction between matrimonial property and maintenance. Both are used to satisfy the goals of 'fairness' or 'proper provision'. The support obligations of marriage are often satisfied by the courts using property redistribution and indeed this method is preferred in the quest for finality.

In contrast, in Scotland there is a clear distinction between maintenance and matrimonial property questions. In Scotland, the court seeks to ensure fair sharing of matrimonial property ${ }^{41}$ and this means equal division unless the circumstances are exceptional. ${ }^{42}$ Periodical payments cannot be used to effect the principle of sharing the value of matrimonial property and are instead used to support the weaker party.

A similar conceptual distinction is seen in French law where a matrimonial property regime can be chosen by the parties. ${ }^{43}$ Once property has been allocated a prestation is used to offset disparity. ${ }^{44}$

\footnotetext{
${ }^{33}$ Charman v Charman [2007] EWCA Civ 503, [64]-[65].

${ }^{34}$ Radmacher v Granatino [2010] UKSC 42.

${ }^{35}$ McCartney v Mills McCartney [2008] EWHC 401 (Fam), [306].

${ }^{36}$ Subject to consideration of the factors outlined in s. 20(2)(a) to (I) of the Family Law (Divorce) Act 1996.

${ }^{37}$ MF v AF [2008] IEHC 164.

38 [2007] IEHC 484.

${ }^{39} T \vee T$ [2002] 3 IR 334 [363]- [364], Keane CJ.

${ }^{40} S D \vee B D$ [2005] IEHC 331.

${ }^{41}$ Section 9(1)(a) Family Law (Scotland) Act 1985.

${ }^{42}$ Section 10(1) Family Law (Scotland) Act 1985.

${ }^{43}$ Art 1387 French Civil Code.

${ }^{44}$ Arts 270- 280-1 French Civil Code.
} 


\section{d) The ongoing nature of the support obligations of marriage.}

In England and Wales, the duration of orders is entirely up to the courts ${ }^{45}$ but subject to the mandate of the Matrimonial Causes Act 1973 that they aim for clean break. This coincides with a preference for lump sum and property readjustment orders wherever possible so that financial obligations for a spouse end on divorce. Where there is no choice but to use periodical payment orders they are variable by the courts.

As one of the key principles behind Scottish law is clean break for the parties, periodical payments are only permitted where a capital sum or property transfer is inappropriate or insufficient and only for a maximum of 3 years. ${ }^{46}$ The main settlement based on sharing is made by property adjustment or a lump sum.

In Ireland, support obligations between the spouses continue for the lifetime of the spouses ${ }^{47}$ unless one remarries ${ }^{48}$ and this includes the possibility of future property readjustment. ${ }^{49}$ This divorce regime is connected to the idea of marriage as an obligation for life and the protection of the stability of the institution under Article 41 of the Irish Constitution.

Although certainty and clean break are encouraged by the Irish courts it is difficult to achieve finality. This idea that support obligations can continue forever and the fact that property readjustment is actually a condition of divorce puts the Irish constitutional imperative of proper provision outside the framework of the EU regimes. It is entirely unconsidered.

\section{EU REgUlation OF THE PRIVATE INTERNATIONAL ASPECTS OF THE DivORCE PROCESS}

The determination of where a couple can sue for divorce and what law should apply to each stage of the process is now subject to EU regulation. The EU regulation of divorce proceedings began in 1999 when the Treaty of Amsterdam ${ }^{50}$ made judicial co-operation in civil matters an area of EU competence. Article 65 of the EC Treaty allowed the Council to take measures "promoting the compatibility of the rules applicable in the Member States concerning the conflict of laws and of jurisdiction". This competence is now found in Article 81 of the Treaty on the Functioning of the European Union ${ }^{51}$ which states that the Union shall develop judicial cooperation in civil matters having cross-border implications, based on the principle of mutual recognition of judgments. This

\footnotetext{
${ }^{45}$ Matrimonial Causes Act 1973, s 28A(1).

${ }^{46}$ Section 9(1)(c), (d) and (e), Family Law (Scotland) Act 1985.

${ }^{47}$ Even in the case of death, a secured maintenance order, made pursuant to section 13(1)(b) of the Family Law (Divorce) Act 1996, will ensure that the liability continues.

${ }^{48}$ Section 13(5), Family Law (Divorce) Act 1996 states that a periodic payment order will automatically cease to have effect on the date of the remarriage of the spouse in whose favour it is made. Section 22, Family Law (Divorce) Act 1996 allows an application to be made to the court for variation of any continuing order on remarriage of either spouse.

${ }^{49}$ Any order made in respect of maintenance on divorce may be varied pursuant to the provisions of section 22 of the Family Law (Divorce) Act 1996, with the exception of a lump sum payment which is not being paid in instalments; JCN v RTN [1999] 1 JIC 1506. Section 14 of the Divorce Act allows the court on granting a decree of divorce or at any time during the lifetime of the respondent spouse to make a property adjustment order; AK $v$ JK [2008] IEHC 341.

50 OJ 1997, C 340/1.

${ }^{51}$ OJ 2008, C 115/47.
} 
competence is no longer limited to ensuring the proper functioning of the internal market. Article 81(3) of the Treaty on the Functioning of the European Union confers on the Council an express power to adopt measures concerning family law having cross-border implications after consulting the European Parliament.

The development of EU regulation of the private international law issues in a cross border divorce has been piecemeal. The first foray of EU law into the divorce courts occurred under the Brussels I regulation. ${ }^{52}$ Although the regulation expressly excluded matrimonial status or rights in property arising out of a matrimonial relationship from its scope, ${ }^{53}$ it governed the recognition and enforcement of maintenance obligations. The Commission explained that once confirmed by a court judgment, a maintenance obligation is considered to be a claim, similar to any other asset-related claim. This is first indication of a tendency to separate the consequences of divorce as financial issues from any overarching family law policy governing the marital breakdown process.

The provisions of Brussels I dealing with maintenance obligations have now been replaced by the Maintenance Regulation. ${ }^{54}$ This regulation simplifies the recognition and enforcement of maintenance claims. ${ }^{55}$ The regulation does not provide for rules of applicable law ${ }^{56}$ but instead refers to the Hague Protocol on the Law Applicable to Maintenance Obligations ${ }^{57}$ which has been signed and ratified by the EU. ${ }^{58}$ The Regulation abolishes the exequatur procedure for decisions given by a Member State that is bound by the Hague Protocol $2007 .{ }^{59}$ In contrast, decisions made by a state which has not signed up to Hague Protocol 2007 will only be enforceable in another Member State, if declared enforceable there. ${ }^{60}$ Thus, maintenance decisions made by states which are signed up to the Hague Protocol are more easily recognized than those from states which have not. The countries which do adopt the Hague Protocol will have harmonized conflicts of law rules in regards to jurisdiction and enforcement and applicable law in maintenance disputes. Those that do not sign up will continue to choose applicable law according to their domestic conflicts of law rules. ${ }^{61}$ This has been criticized by some commentators as creating a two tiered Europe. ${ }^{62}$

The EU moved on to harmonizing the rules governing a court's jurisdiction to grant a divorce and the rules applicable to the recognition and enforcement of foreign divorce decrees. The first instrument, Brussels II ${ }^{63}$ was introduced in June 2000 and later replaced in Brussels II bis. ${ }^{64}$

\footnotetext{
${ }^{52}$ Regulation 44/2001 EC [2001] OJ L 12/1.

53 Ibid Art 2.

${ }^{54}$ Regulation 4/2009 EC [2008] OJ L 7/1. This regulation came into force on 30 January, 2009 and shall apply from 18 June 2011.

${ }^{55}$ Identified as the main problems with the functioning of the regulation. See, Hellner $M$ "The Maintenance Regulation: A Critical Assessment of the Commission's Proposal" in in K Boele-Woelki and T Sverdrup (eds), European Challenges in Contemporary Family Law (European Family Law, Intersentia, Antwerp 2008) 347.

${ }^{56}$ Although this was in the original proposal.

${ }^{57}$ supra $\mathrm{n} 54$, Art 15.

${ }^{58}$ Council Decision 2009/941 EC [2009] OJ L331/17.

${ }^{59}$ supra n54, Art 17.

${ }^{60}$ Ibid Art 26.

${ }^{61}$ As the EU has signed and ratified the Hague Protocol this will mean that only Denmark and the UK remain outside it. supra n58 recitals (11)- (12) See, Beaumont P "International Family Law in Europe - The Maintenance Project, the Hague Conference and the EC: A Triumph of Reverse Subsidiarity," (2009) 73 RabelsZ Bd., 545.

62 Bremner, P "The EU Maintenance Regulation: A qualified success for European Family Law," (2010) 2 Kings Student Law Review, 5.

${ }^{63}$ Regulation 1347/2000 EC [2000] OJ L 160/30.

${ }^{64}$ Regulation 2201/2003 EC [2003] OJ L 338/1, added a range of rules on the mutual enforcement of judgments on the rights of access to children. There was no amendment to the measures on nullity, divorce
} 
The scope of Brussels $\|$ bis $^{65}$ is limited to proceedings relating to the marital bond itself such as divorce, legal separation and nullity decrees. ${ }^{66}$ Although divorce proceedings often include rulings on economic arrangements, technically, the recognition of these arrangements falls outside Brussels II bis and is covered by the Maintenance Regulation in the case of maintenance, and national law or international conventions in the case of matrimonial property issues. However, a court which is competent pursuant to the Brussels II bis will generally have jurisdiction to rule on ancillary maintenance matters. ${ }^{67}$

Rome $1 \mathrm{II}^{68}$ developed out of a proposal in 2006 to amend the jurisdictional rules of Brussels II bis and introduce rules harmonizing the applicable laws to matrimonial status decisions. ${ }^{69}$ It was argued that harmonised applicable law rules would reduce the risk of parties rushing to court or forum shopping in the case of divorce. Regardless of the jurisdiction invoked by the parties, the substantive divorce law governing the end of the marriage would be designated by common rules. ${ }^{70}$ Under Rome III it would become impossible to escape the correct applicable law; the law of the marriage would be applied no matter where the case was heard.

Under the original proposal for Rome III, spouses were permitted to choose which court would have jurisdiction to hear their divorce proceedings and the applicable law to their divorce.

The reception to the proposal was mixed. The Dutch Parliament initially rejected the proposed harmonization of divorce choice of law as being contrary to the principles of subsidiarity and proportionality and on the ground that there was no evidence that the Commission's proposal would enhance the proper functioning of the internal market. ${ }^{71}$ Ireland and the UK exercised their opt-outs.

The unanimity required to adopt Rome III as the new version of Brussels II bis was not achieved. In 2008 Greece, Spain, Italy, Luxembourg, Hungary, Austria, Romania and Slovenia indicated to the Commission that they wished to establish enhanced co-operation between themselves in the area of applicable law to matrimonial matters. Between 2008 and 2010, Bulgaria, France, Germany, Belgium, Latvia, Malta and Portugal requested enhanced co-operation in this area. The Council authorised enhanced co-operation in this area on 12 July 2010. ${ }^{72}$ This was justified on the basis of legal certainty, predictability and to prevent a rush to court.

and separation although the numbering of the articles has changed. Annex V of Reg 2201/2003 showing correspondence between articles of Brussels II and Brussels II bis. For the sake of clarity the Brussels II bis article numbers will be used throughout.

${ }^{65}$ Regulation 2201/2003, Art 1.

${ }^{66}$ A Borrás, "From Brussels II to Brussels II bis and Further" in K Boele-Woelki and C Gonzalez Beilfuss (eds) Brussels II bis: Its Impact and Application in the Member States (CEFL, Intersentia, Antwerp 2007).

${ }^{67}$ Regulation 2201/2003, Art 3 (c). cf Moore infra n 111.

${ }^{68}$ Regulation 1259/2010 EU [2010] OJ L343/10.

${ }^{69}$ Proposal for a Council Regulation Amending Regulation (EC) No 2201/2003 as Regards Jurisdiction and Introducing Rules Concerning Applicable Law in Matrimonial Matters. Brussels 17 July 2006 COM (2006) 399 final.

70 Ibid, 4.

${ }^{71}$ Letter to the European Commission dated 26 September 2006: Kamerstukken 2006-2007 30671 E and no 5 cited in T de Boer, "The Second Revision of the Brussels II Regulation: Jurisdiction and Applicable Law" in K Boele-Woelki and T Sverdrup (eds) European Challenges in Contemporary Family Law (CEFL, Intersentia, Antwerp 2008).

${ }^{72}$ Council Decision of 12 July 2010 authorising enhanced cooperation in the area of the law applicable to divorce and legal separation (2010/405/EU) OJ L 189/12. 
Rome III was adopted in December 2010 and will apply from 21 June 2012. Unlike the Commission's original proposal, the enhanced cooperation measure concerns only applicable law and not jurisdiction, the aim being to avoid affecting Brussels II bis. 14 Member States ${ }^{73}$ have signed up to enhanced co-operation leaving 13 countries to their own domestic conflicts of law rules to determine the law applicable to divorce or legal separation. ${ }^{74}$

There is another regulation proposal to deal with cases concerning the division of matrimonial property - Rome IV. ${ }^{75}$ This proposed regulation is currently at the drafting stage. A Green Paper was published in $2006^{76}$ and on 5 February 2008, the European Commission published a summary of the 40 replies which it had received from governments, academia and associations. ${ }^{77}$

The question structure of the consultation paper shows a leaning towards the civil law system of matrimonial breakdown. It treated the question of matrimonial property as a very different and separate question to the issues of granting divorce or awarding maintenance. It also showed a preference for the use of binding matrimonial property agreements. This assumption that binding prenuptial agreements best preserve the autonomy of the spouses is a view not traditionally shared in England and Ireland.

The principles on which the proposal is based are certainty for creditors and spouses and autonomy of the spouses. In the impact report ${ }^{78}$ the specific objectives for Rome IV were laid out. They included, allowing spouses to predict what law would be applied to the management of their property in the absence of choice, allowing the spouses to bring all matters involving their divorce to the same court, to facilitate recognition and enforcement of judgments and to tackle the problem of inadequate information on applicable property regimes. There was little reference to the idea that property might need to be redistributed on breakdown according to need or fairness.

The analysis of the answers to the consultation did draw attention to the fact that "England and Wales do not have a matrimonial property regime as understood in continental Europe" ${ }^{\prime 79}$ but it was claimed that the "usefulness of a Community initiative on this issue was not contested".

An expert group was appointed in 2008 to draft the new regulation and it is anticipated that a draft version of Rome IV will be published in 2011. However, at the 4th Conference of the Commission on European Family Law in 2010 in Cambridge, Ulf Bergquist, a member of the EU Commission's expert group for international succession and matrimonial property law gave an overview of progress so far. At this point, a draft Rome IV had been drawn up but had not yet been approved by the Commission.

The scope of the regulation had been limited to matrimonial property disputes upon divorce or death, cohabitation has not been included. Tax matters, maintenance obligations, gifts between spouses and succession rights have been excluded from the scope of the regulation. ${ }^{80}$

\footnotetext{
${ }^{73}$ Greece withdrew its request in 2010.

${ }^{74}$ Rome III will only cover divorce and legal separation and does not apply to annulment (Article 1).

${ }^{75}$ Green paper on Conflict of Laws in Matters Concerning Matrimonial Property (SEC(2006) 952) COM(2006) 400 final.

${ }^{76}$ Ibid.

77 Ireland and Malta did not respond.

http://ec.europa.eu/civiljustice/news/docs/summary answers com 2006400 en.pdf accessed on 2

February 2011.

78 Ibid.

79 Ibid p2. No mention was made of Ireland or Scotland

${ }^{80}$ Chapter I.
} 
What was clear from the presentation of the committee is that Rome IV is designed to work in systems where the question of matrimonial property is dealt with separately from the question of divorce status and the personal effects of marriage. This EU focus on snapshots of the divorce process fails to consider the division of matrimonial property in the context of matrimonial breakdown. This is arguably the natural result of a tendency to use property lawyers rather than family lawyers on drafting committees in this area.

The intervention of the EU into this area of family law can only be justified on a step by step basis. The regulation of maintenance under Brussels I was justified as being part of the free movement of money claims throughout the EU. Thus intervention was required under Article 65 of the EC Treaty to ensure the proper functioning of the internal market.

The rationale for Brussels II bis was that the rules of jurisdiction in matrimonial matters and in matters of parental responsibility hampered the free movement of people in the union. ${ }^{81}$ As far as divorce matters were concerned this meant that limping marriages should be prevented and it is at least tenable that this matter could not have been dealt with at national level. However, no empirical evidence of the problem was presented.

The justification for Rome III was that while Brussels II bis had established common rules of jurisdiction based on a large number of connecting factors it did not regulate what law these courts would apply to divorce. It was claimed that the difference between national laws led to uncertainty regarding marriage dissolution and, often the law applied did not correspond to the legitimate expectations of EU citizens. ${ }^{82}$ This problem could potentially affect tens of thousands of EU citizens per year as this represented the number of international divorces.$^{83} \mathrm{~A}$ similar rationale is given for the need to legislate for Rome IV. ${ }^{84}$ The practical and legal difficulties are alluded to and numbers of cases are extrapolated from the impact study for Rome $1 \mathrm{II} .{ }^{85}$

As the work of the EU only applies to private international law issues, it could be argued that there is no direct interference with the domestic law of Member States. The regulations merely allow internationally mobile couples to get a divorce under the law of the state most connected to them.

The policy goals behind the EU regulations include autonomy, equality and certainty. Boele-Woelki argues that most Member States have such concerns on the breakdown of marriage. ${ }^{86}$ Thus the EU regulations do not make new policy but rather reflect the common values of the Member States. However the interpretation of these policy concerns and their relative weight is not the same throughout the Member States. ${ }^{87}$

\footnotetext{
${ }^{81}$ Regulation 1347/2000, Recital (4).

${ }^{82}$ Proposal for a Council Regulation Amending Regulation (EC) No 2201/2003 as Regards Jurisdiction and Introducing Rules Concerning Applicable Law in Matrimonial Matters. Brussels 17 July 2006 COM (2006) 399 final, p3.

${ }^{83}$ The public consultation and the impact assessment carried out at the time of the Commission's July 2006 proposal have demonstrated that the scale of the problems addressed by the present proposal is significant and concerns tens of thousands of citizens each year, although it is not clear if $100 \%$ of these citizens suffer problems. http://eur-lex.europa.eu/LexUriServ/LexUriServ.do?uri=CELEX:52006SC0950:EN:NOT accessed on 2 February 2011.

${ }^{84}$ Supra, $\mathrm{n} 75$.

${ }^{85}$ Supra, $\mathrm{n} 83$.

${ }^{86}$ Boele-Woelki Unifying and Harmonizing Substantive Law and Role of Conflicts of Law, (Pocketbooks of the Hague Academy of International Law, Martinus Nijhoff, 2010) [3.1.4].

${ }^{87}$ See further, D Bradley "A Family Law for Europe? Sovereignty, Political Economy and Legitimation.," [2004] Global Jurist Frontiers.
} 
For example, in Sweden divorce is considered a fundamental right and essential part of equality between men and women. Whereas in Ireland unlimited right of redistribution of assets is considered to be part of fundamental equality between men and women. Both countries respect the right to equality but in radically different ways. In the Rome III, Article 12 the word "manifestly" means that use of the public policy exception to refuse to apply foreign law must be exceptional.

Under the EU regime, there are signs of slight policy preferences towards a swift divorce and certainty of financial outcome rather than ensuring that divorced spouses are provided for. This effectively favours the domestic policy of some Member States over others. Brussels II bis favours those who move quickly to court making the jurisdiction of Member States with lengthy separation requirements or heavy reconciliation requirements less likely to be seised in international divorces. Article 10 of Rome III requires the law of the forum to be applied where the applicable law does not provide for divorce. Thus a couple who were last commonly habitually resident in Malta, or have chosen the law of Malta to govern their divorce will not have that law applied in countries that have opted into Rome III. While some Member States have deliberately chosen to opt out of Rome III, it does send out a clear message that some types of divorce are preferable and where there is a choice to be made between two regimes, one is to be favoured.

If Rome IV comes into force, a complicated EU legislative framework will form, applicable to international divorce cases and the consequences of such divorces. The basis for Rome III and Rome IV appears to be convenience for practitioners and certainty for the parties. It is not clear if any of these aims are achieved by the legislation. The absence of clear characterisation will make the regime initially unwieldy and the fact that so many regulations could potentially be involved will necessarily make the system more difficult for spouses to understand rather than less difficult. It is impossible to tell what the demand for such legislation is, in the absence of proper empirical research. The solution that emerges is piecemeal rather than being a coherent approach to simplifying the process of divorce across the European Union.

\section{Characterisation Within the Regime}

Each EU regulation is relevant only to one issue within the divorce process. Brussels I makes a clear distinction between "rights in property arising out of a matrimonial relationship" ${ }^{88}$ and "matters relating to maintenance." ${ }^{\prime 99}$ The recitals to Brussels II bis exclude "property consequences of the marriage or any other ancillary measures", ${ }^{90}$ and state that "maintenance obligations are excluded". Article 2 of Rome III expressly excludes maintenance and matrimonial property from its scope. The proposed Rome IV will expressly exclude maintenance from its scope.

This focus on the individual issues of matrimonial status, maintenance or matrimonial property necessitates distinguishing these issues clearly from one another. In this section it is argued that this characterization by the EU regime is difficult to apply in systems which do not have a clear conceptual difference between maintenance and property and this issue will require further clarification from the ECJ.

The distinction between maintenance and matrimonial property is easy to make in many civil law regimes where there are different sections of the code applying to matrimonial financial obligations

\footnotetext{
${ }^{88}$ Regulation 44/2001, Art 1.2(a).

${ }^{89}$ Ibid Art 5.3.

${ }^{90}$ Regulation 2201/2003, Recital (8).
} 
and matrimonial property. ${ }^{91}$ In such systems, maintenance and property are conceptually different. The obligations of marriage cease on divorce in most cases. Maintenance obviates any inequality and property needs to be sorted out and allocated to the true owner.

In contrast, under the common law system in England and Ireland, the obligation to support in marriage is satisfied by both maintenance and property transfer upon divorce. This means that the line between matrimonial property and maintenance is not easy to draw, particularly in relation to lump sums, secured maintenance and 'Mesher' ${ }^{\prime 2}$ orders.

The Green Paper on Rome IV defines a matrimonial property regime as "matrimonial property rights of the spouses" and "the sets of legal rules relating to the spouses' financial relationships resulting from their marriage." The Maintenance Regulation does not define a maintenance obligation but Recital 12 states that it should be interpreted autonomously.

The ECJ ruled on the distinction between 'maintenance' and 'matrimonial property' in Van den Boogaard $v$ Laumen. ${ }^{93}$ This case involved a couple who had married in the Netherlands and chosen a separation of goods regime for their matrimonial property. The couple subsequently moved to London and upon divorce, the wife sought ancillary relief under Part II of the Matrimonial Causes Act. When the wife sought to have the orders enforced in the Netherlands the question of whether they could be recognised under the Brussels Convention was raised. The Dutch courts, thinking that these orders were more likely related to matrimonial property than maintenance, ${ }^{94}$ referred the question to the ECJ.

Advocate General Jacobs stated that maintenance did not merely refer to periodical payments. ${ }^{95}$ The provisions of English law meant that the distinction between equitable division of assets and maintenance was rather arbitrary. ${ }^{96} \mathrm{~A}$ lump sum could be related either to maintenance or division of matrimonial property and a national court should look to the individual order to see if its primary purpose was maintenance within the autonomous meaning of that term. ${ }^{97}$

The ECJ ruled that a national court should look to the reasoning of the decision of an English court to decide if its order was enforceable as maintenance. When a provision awarded is designed to enable one spouse to provide for herself or if the needs and resources of each of the spouses are taken into consideration in the determination of its amount, the decision will be concerned with maintenance. On the other hand, where the provision awarded is solely concerned with dividing property between the spouses, the decision will be concerned with rights in property arising out of a matrimonial relationship and will not therefore be enforceable under the Brussels Convention. ${ }^{98}$ In the case of a mixed order, part would be enforceable.

The ECJ test for deciding if an order is maintenance or matrimonial property relies on a clear explanation by the awarding court of the purpose of the order. However, this can be difficult to

\footnotetext{
${ }^{91}$ For example the duty and scope of family maintenance is described in $\S \S 1360-1360 \mathrm{~b}$ of the German Civil Code whereas matrimonial property regimes are in an entirely different section ( $\S 1363$ et seq. German Civil Code for the community of accrued gains, in $\S \S 1415$ et seq. German Civil Code for the community of property and in $\S 1414$ German Civil Code with regard to the separation of property.)

${ }^{92} \mathrm{~A}$ type of settlement of the matrimonial home until the children have reached adulthood. See, Mesher $v$ Mesher [1980] 1 All ER 126.

${ }^{93}$ C-220/95 Boogaard v Laumen [1997] ECR I-1147, [1997] QB 759.

${ }^{94}$ Ibid [15].

${ }^{95}$ Ibid [41].

${ }_{96}^{96}$ Ibid [62] AG Opinion.

${ }^{97}$ Ibid [43].

${ }^{98}$ Ibid [22].
} 
establish. The purpose of English ancillary relief is not statutorily defined. It would seem that under the three stage test of Miller; McFarlane, needs and compensation could be identified as maintenance, leaving only sharing the fruits of the marriage as an issue strictly to do with marital property. In Ireland, the conceptually ill-defined 'proper provision' will be difficult to divide into maintenance and division of property. $\ln T v T$, Keane $\mathrm{CJ}$ expressly stated that the Irish courts were not concerned with division of property but with proper provision. ${ }^{99}$ Most Irish judgments merely apply the factual checklist but do not explain the purpose of the final orders beyond describing them as proper provision.

Moreover, the Boogaard test was designed to establish whether or not an existing order was enforceable. It is unclear to what extent the test is useful in determining applicable law where a court is required to apply the law of one country to the question of maintenance and other to the question of matrimonial property.

The issue of whether or not a decision on marital property can actually be binding as a condition for the granting of divorce under Brussels II bis has yet to addressed by the ECJ and was not considered in the Green Paper on Rome IV.

\section{E. THE INTER-RELATION OF THE EU REGULATIONS}

Under the EU regime, jurisdiction to grant divorce will be determined by Brussels II bis and applicable law for this decision will be determined by Rome III, where the Member State has adopted this regulation. ${ }^{100}$ The issue of jurisdiction and applicable law for maintenance issues will be governed by the Maintenance Regulation and the Hague Protocol. The questions raised on the division of matrimonial property are to be answered by reference to Rome IV, which is currently in proposal form.

Even if the issues of divorce status, maintenance and matrimonial property were easily distinguished from each other, the application of these regulations to an international divorce is a complicated process. It is possible for different issues to end up in different courts. The jurisdiction grounds of Brussels II bis are not hierarchical so where the couple have a basis to bring a petition for divorce in more than one Member State it is the first to court who will determine where many of the issues are heard. This will determine whether Rome III will apply and the applicable law will determine whether issues of maintenance and property must be determined at this time. Where maintenance and property issues are left completely to the parties with no court approval, such as under the English system, it is possible for these issues to be raised in a totally different court to that granting divorce, years later.

Even where one court became seised of all aspects of the divorce dispute, different applicable law could apply to different aspects of the divorce because the connecting factors for applicable law are different for all four regulations. ${ }^{101}$ This would lead to legal effects which could not happen under one legal system. This could, in certain cases, lead to absurd results that no legislator would have wanted and ignores the reality that in each legal system rules are set to create a coherent framework. ${ }^{102}$

\footnotetext{
${ }^{99} T v T$ [2002] 3 IR 334 [363]- [364], Keane CJ [368]-[9].

${ }^{100}$ Or national conflict of law rules if the Member State has not opted in.

${ }^{101}$ Brussels II bis, the Maintenance regulation and the proposed Rome III and Rome IV.

102 A Fiorini "Rome III - A Step Too Far in the Europeanisation of Private International Law?" (2008) 22 International Journal of Law, Policy and the Family, 178-205.
} 
The lack of clarity on the difference between a status decision, matrimonial property and maintenance will make the new regime particularly difficult to use where the applicable law does not itself distinguish clearly between these issues.

\section{The Potential for Different Applicable Law}

Applicable law rules under Rome III, IV and the Maintenance Regulation are based on different connecting factors.

Under Article 5 of Rome III the law chosen by the parties is applicable to the grant of divorce. This choice is limited to the law of state where the couple were habitually resident when the divorce was concluded, the law of the state where the couple were last habitually resident when the divorce was concluded if one of them still lives there at the time of the conclusion of the agreement, the law of the country of the nationality of either spouse or the law of the forum. In the absence of choice, Article 8 lays down a hierarchy of mutable factors. The law applicable will be the law of where both parties are habitually resident at the time the court is seised. Failing that, the law applicable is the law of the last joint habitual residence of the spouses providing that one spouse still lives there and both spouses lived there less than one year previous. Failing that, the law applicable is the law of the country where both spouses are nationals and failing that, the law applicable is that of the forum.

The applicable law under Rome III is mutable, as the couple change joint habitual residence the law applicable to their divorce also changes regardless of where they were originally married. The applicable law can be that of a Member State that has not signed up to Rome III. ${ }^{103}$ Thus a court could be mandated to apply Irish or English law under Rome III.

The applicable law rules of the Maintenance Regulation come from the Hague Protocol $2007 .{ }^{104}$ The general rule under Article 3 is that the applicable law is the law of the habitual residence of the creditor. This is again a mutable connection and changes when the creditor moves habitual residence. However, a particular rule relevant to ex spouses ${ }^{105}$ states that Article 3 will not apply if one of the spouses objects and another state has a closer connection, in particular the law of the last common habitual residence. In such a case that law will apply. Article 6 allows a debtor to contest a claim where the obligation would not exist both in the law of the habitual residence of the debtor and the law of the state of the common nationality of the parties.

Under the proposed Rome IV, the applicable law is that of the common habitual residence of the spouses when they got married. This is an immutable or petrified system so the applicable law will not change if the couple move from one Member State to another.

These three regulations read together mean that it is possible for the law of last common habitual residence to apply to the grant of divorce state, the law of the current habitual residence of the creditor to apply to the issue of maintenance and the law of the first common habitual residence to apply to the issue of matrimonial property!

In general, there will be a disconnect between property and maintenance when a couple move from one country to another. This will mean that courts will quite often have to apply foreign law to

\footnotetext{
103 Regulation 1259/2010, Art 4.

104 Protocol on the Law Applicable to Maintenance Obligations (Concluded 23 November 2007) http://www.hcch.net/upload/conventions/txt39en.pdf accessed on 2 February 2011.

${ }^{105}$ Ibid, Article 5.
} 
matrimonial property issues ${ }^{106}$ whereas for maintenance and divorce the courts will be most likely to apply domestic law. This would seem to ignore some of the policy aims under common law 'package type' systems of ensuring that where there is a dispute on the financial consequences of marriage all parties are held to the level of financial support they signed up to when they married under the common law system. The application of two legal regimes to the consequences of divorce may also be quite at odds with the expectations of the parties.

It is open to a couple to make an agreement about applicable law to avoid this atomisation of their divorce proceedings. Although the couple could make a choice to have the same law applicable to all aspects of their divorce, this choice is limited and the limitations are not the same in each regulation.

The Maintenance Regulation allows the greatest choice of applicable law. This choice is limited to the law of any State of which either party is a national, habitual residence of either party at the time of the designation or the law applicable to the parties' divorce, matrimonial property regime or legal separation. ${ }^{107}$

This means that it is possible to choose one law for maintenance, the place of one party's habitual residence that could not be chosen as the law applicable to the divorce under Rome III. ${ }^{108}$

Under Rome IV the couple can choose the applicable law to govern their matrimonial property. ${ }^{109}$ The choice is limited to countries to which the couple has a real connection. The same law must be chosen for all assets. The agreement can be changed at any time up until the dispute and third parties must be considered.

The atomization of the work in this area is explained by the fact that it was easier to achieve consensus on these issues taken in isolation than it would have been had work been undertaken on a wider area of family law. ${ }^{110}$ For each stage of the divorce process, the chosen connecting factor for applicable law is the one most suited if the stage is viewed in isolation. Present common habitual residence is most suited for determining the grounds for divorce because that is the state in which the couple have chosen to make their home. However, the certainty required in relation to matrimonial property regimes means that the applicable law in relation to this must be fixed early on. This simplification of the divorce process into three seeming detached issues will inevitably result in a complex situation for spouses involved in transnational divorce. Co-ordination between the instruments is a clear necessity.

\section{Problems where the applicable law does not distinguish between property and maintenance.}

The test laid down in Boogaard is one designed to identify the nature of an existing court order, thus the court looks at the reasoning of the court that made the order seeking to be enforced. It is a

\footnotetext{
${ }^{106}$ Kroll K "Unification of Conflicts of Laws in Europe" in Boele-Woelki and Sverdrup (Ed) European Challenges in Contemporary Family Law (Intersentia 2008) 390.

${ }^{107}$ Regulation 4/2009, Art 8.

${ }^{108}$ M Hellner, "The Maintenance Regulation: A Critical Assessment of the Commission's proposal" in K BoeleWoelki and T Sverdrup (eds), European Challenges in Contemporary Family Law (Intersentia, Antwerp 2008) 355.

${ }^{109}$ Chapter 3 supra nn79-80.

${ }^{110}$ A Fiorini "Rome III - A Step Too Far in the Europeanisation of Private International Law?" (2008) 22 International Journal of Law, Policy and the Family, 178-205.
} 
different question when the court is asked to award maintenance under one system of applicable law and divide matrimonial property under another.

The decision to award maintenance under a domestic system is often expressly linked to the division of matrimonial property. For example under French law, maintenance is only awarded to redress an imbalance once matrimonial property has been accorded. In contrast, under English law there could only be said to be property division once needs and compensation are provided for.

It will be very difficult to apply only the maintenance or matrimonial property law in isolation where one of the applicable regimes is a common law 'package' solution. For example it will be difficult to establish what principles to apply to the division of matrimonial property in the absence of the first two strands of the Miller:McFarlane test. Similarly under Irish law, it will be difficult to establish how property should be divided on the basis of 'proper provision' if maintenance has already been addressed under a different applicable law.

Applying the Boogaard test to a situation where maintenance is to be awarded under one legal system and property division under another has proved rather unsatisfactory. In Moore v Moore ${ }^{111}$ a very wealthy English couple emigrated to Spain to avoid tax. The husband applied to the Spanish courts for a divorce but did not initially seek a ruling on financial relief from the Spanish courts. The wife applied for divorce and financial relief in the English courts but her petition was refused as her husband's petition to the Spanish courts was first in time and Brussels II gave this priority. During the process of the Spanish divorce, the couple attempted to come to a private settlement but this was not successful. When negotiations broke down the husband applied to the Spanish courts for a determination of financial claims but the Spanish court held that it had no jurisdiction to hear the matter as this had not been included in the petition. ${ }^{112}$ The wife obtained leave to apply for additional financial relief following an overseas divorce in England under s 13 of the Matrimonial and Family Proceedings Act $1984 .{ }^{113}$ The husband appealed the Spanish decision and applied to have his wife's application to the English courts set aside on the basis that this was a maintenance claim and the Spanish courts had jurisdiction under Brussels I.

The Court of Appeal held that whether or not the pending claim in the Spanish court constituted maintenance was to be determined according to the autonomous meaning of maintenance. As there was no reasoning of a court to look to, they looked to the wording of the husband's petition to apply the Boogaard test. As the husband had applied for 'wealth adjustment' this was deemed to be a case of property division rather than maintenance. ${ }^{114}$ The court held that this was an attempt by the husband to achieve sharing of his property within the meaning of the third strand of the Miller:McFarlane test. ${ }^{115}$ Thus the UK had jurisdiction to make an award.

Moore shows the difficulties of applying the Boogard test to a petition rather than an order with the wording of the order proving particularly important. It is clear that this issue will require further examination by the ECJ in cases where different law will be applicable to maintenance and matrimonial property.

\footnotetext{
111 [2007] EWCA Civ 361.

112 Ibid [19].

113 Ibid [21].

114 Ibid [88]-[90].

115 Ibid [94].
} 


\section{F. COMMON LAW COMPATIBILITY ISSUES WITH THE REGIME}

It is argued that the easy disconnect between the law applicable to maintenance and matrimonial property shows that this regime is designed to function within a civil system where these two aspects are conceptually distinct. The regime also assumes an acceptance of matrimonial property agreements.

While the common law system can be made to fit the characterisation of the EU regime (property orders and pre-nuptial agreements can be compared to property regimes, maintenance is roughly equivalent to periodic payments) it is submitted that this is like sticking a round pin into a square hole, and ignores the policy concerns behind 'package solutions' to the consequences of divorce.

Where a foreign court has already ruled on maintenance or property there is evidence to suggest that both the Irish and English courts may amend that ruling without expressly declaring their refusal to recognise it, where the award does not accord with domestic policy about the basic financial obligations of marriage.

The other area of potential incompatibility is refusal by common law courts to enforce binding agreements on the financial consequences of marriage.

\section{a) No agreement situations}

Where a foreign divorce or legal separation is recognised in Ireland, section 23 of the Family Law Act 1995 allows a spouse to apply for addition ancillary relief under Irish law by means of an ex parte application.

In $M R \vee P R^{116}$ a couple had married in Ireland in 1976 and divorced in Spain in 1996. The husband had paid the wife a sum of $£ 50,000$ to satisfy the maintenance requirements of the Spanish divorce proceedings. However, the wife later discovered that he was the beneficiary of a trust worth $€ 2,900,000$. As she had no recourse under Spanish law, she sought relief from the Irish courts. Quirke J found that it was legitimate to fill in the blanks left by a foreign court and review or rectify a decision of the court. However, he placed limits on the power of an Irish court to review the substantive points of a divorce settlement stating:

The statutory relief granted [under Part III of the 1995 Act] is not intended to compensate the applicant for past financial or other hardship or inequity. It is intended to alleviate present inequitable financial or other hardship or reduced circumstance caused by a seemingly unjust outcome resulting from divorce proceedings in another jurisdiction where no comparable remedy is now available to the applicant. It is intended to do so in a just and equitable fashion. ${ }^{117}$

The case does not mean that the Irish courts are permitted to impose their own judgment on the support obligations of the parties to a marriage where another foreign court has already ruled on the issue but rather to make a fresh determination based on current circumstances. The Family Law Act 1995 gives the Irish courts jurisdiction to do this. Some commentators argue that the distinction made by Quirke J that this was not a review of the foreign judgment but merely filling the gap is not persuasive and that the existence of a gap is a purely subjective assertion. ${ }^{118}$

\footnotetext{
${ }^{116} M P \vee P R[2005] 2$ IR 618 (IEHC).

117 Ibid 639.

118 R Aylward, Marriage, Pre-Nuptial Agreements and Irish Law (TCD 2006) 183.
} 
However, the case could also be understood as characterising this subsequent order, not as a matter of maintenance or matrimonial property, but as an obligation based on duty to support a former spouse under Irish law that is triggered by current circumstances. This would mean that it would fall outside the EU regulations. ${ }^{119}$

In Agbaje v Agbaje ${ }^{120}$ the UK Supreme Court considered whether an award of maintenance made in another Member State, would preclude the application of Part III of the Matrimonial and Family Proceedings Act 1984 on the basis that the issue of maintenance had been determined in the other jurisdiction and that that determination was entitled to recognition. ${ }^{121}$ Lord Collins noted that it would depend on whether the application was to be characterised as relating to maintenance or to rights in property arising out of a matrimonial relationship. He stated that this was an area which involved "difficult questions which do not arise for decision on this appeal." 122

However, Lord Collins warned that it is not the purpose of Part III to allow a spouse with some English connections to make an application in England to take advantage of a more generous approach in England to financial provision. ${ }^{123}$ He held that mere disparity between an award and what would be awarded on an English divorce will be insufficient to trigger the application of Part III. However the court held that hardship is not a precondition of an award.

The logic of the English courts in enforcing the English obligations of marriage makes sense where the parties are English, have married in England and have identified with the commitments of English marriage law. ${ }^{124}$ This can be seen to stem from the idea of marriage as a public commitment to the law of a particular system. Where the courts are forcing English marriage commitments on spouses who do not have such a strong connection to England the discomfort of the court is noticeable. ${ }^{125}$ It is fine to insist on the application of English policy to a divorce where there is a connection to England but anathema to hold foreign couples to such rules. The logic of the English courts is that such couples should be held to the public obligations of marriage they took on in their own countries.

\section{b) Agreement situations}

Under Rome III, party autonomy to choose the applicable law for their divorce is safeguarded and choice of law must be informed. ${ }^{126}$ Under Rome IV the couple can choose the applicable law to govern their matrimonial property. This decision to allow couples to choose the law of divorce and the law of their matrimonial property is based on the importance that the EU accords to party autonomy. ${ }^{127}$ It does not completely privatise the obligations but they may choose a selection of obligations from the countries to which they are connected. ${ }^{128}$

\footnotetext{
${ }^{119} \mathrm{G}$ Shannon, "The Impact and Application of the Brussels II bis Regulation in Ireland" in K Boele-Woelki and C Gonzalez Beilfuss (eds) Brussels II bis: Its Impact and Application in the Member States (Intersentia, Antwerp 2007) 159.

${ }^{120}$ [2010] UKSC 13.

${ }^{121}$ Ibid [57]

${ }^{122}$ Ibid.

${ }^{123}$ Ibid [72].

${ }^{124}$ Moore, supra n111, [110].

${ }^{125}$ Radmacher $v$ Grantino [2009] EWCA Civ 649 [11].

${ }^{126}$ Regulation 1259/2010, Recital (18).

${ }^{127}$ Supra n69, 4.

${ }^{128}$ Regulation 1259/2010, Recital (15).
} 
Clearly the EU is not ready to condone unilateral autonomy after the breakdown of the marriage by one party to take advantage of an advantageous legal system: the initial premise for Rome III was to prevent forum shopping by the parties. ${ }^{129}$ Autonomy must be expressed as a couple. Neither are you permitted to choose any law for your marriage, it must be one to which you have a substantial connection. ${ }^{130}$ Rome III does not apply to nullity which is determined by the domestic rules of the court seised under Brussels II bis. Thus the EU has not entirely abandoned the idea of marriage as a public commitment but merely allows couples with connections with more than one Member State to choose the legal system that represents the public commitment of their marriage while trying to prevent advantage being taken where that choice is not clearly expressed.

However, English and Irish courts do not allow spouses to choose the law applicable to their divorce or its financial consequences. The jurisdiction that the court exercises in such cases is to impose the public obligations of marriage, thus an agreement that holds the spouses to a lesser standard than 'proper provision' or 'fairness' will be ignored even if that agreement merely chooses the law of another Member State. Either the solution proposed in the agreement is fair according to English standards or it is not. ${ }^{131}$

In Radmacher, the Supreme Court held that foreign jurisdiction clauses or choice of foreign law agreements were entirely irrelevant to the exercise conducted by the court when discharging its duties under Part II of the Matrimonial Causes Act 1973. ${ }^{132}$ This is power given to the English Courts by English law and so it cannot apply foreign law when conducting this exercise. The jurisdiction given to the English Courts by Part II of the Matrimonial Causes Act 1973 is un-oustable. ${ }^{133}$ While this approach can be criticised by as being insular, it makes sense if marriage is viewed as a public commitment rather than a private contract. The English courts are responsible for enforcing the public commitments of an English marriage, thus when the court exercises jurisdiction to award financial relief it is these English obligations that it enforces.

The UK used to treat the issue of matrimonial property contracts by transferring jurisdiction on their effect to the country of their formation. In $D \vee P^{134}$ before the implementation of Brussels II bis, the English courts granted a divorce to a Dutch husband and an Italian wife. However the English High Court granted a stay to ancillary relief hearings and declined jurisdiction over the wife's maintenance on the grounds that the Italian court was better placed to rule on this issue because it had jurisdiction over child maintenance.

This bifurcation solution has continued to be used in England where there is a non EU Member State with jurisdiction to hear a divorce or maintenance issue even where the UK has jurisdiction to grant divorce under Brussels II bis. This practice seems set to continue if unchecked by the ECJ. In Cook v Plummer $^{135}$ Lord Justice Thorpe held that the invocation of Owusu ${ }^{136}$ in family cases to prevent the court transferring jurisdiction granted under Brussels II bis was not a straight forward argument. He noted that "Owusu is deeply unpopular in this jurisdiction" and that the UK is currently seeking to

\footnotetext{
129 Proposal for a Council Regulation Amending Regulation (EC) No 2201/2003 as Regards Jurisdiction and Introducing Rules Concerning Applicable Law in Matrimonial Matters. Brussels 17 July 2006 COM (2006) 399 final, 2006/0135 (CNS). 4.

${ }^{130}$ Regulation $1259 / 2010$, Art 4.

131 Radmacher v Granatino [2010] UKSC 42, [73].

132 Ibid [74].

${ }^{133}$ Hyman v Hyman [1929] AC 601.

${ }^{134} D \vee P[1998] 3$ FCR 403.

135 [2008] 2 FLR 989.

${ }^{136}$ Owusu v NB Jackson (trading as Villa Holidays Bal-Inn Villas) and others (Case C-281/02) [2005] All ER (D) 47.
} 
mitigate its unattractive effect by submissions to the review of Brussels I. ${ }^{137}$ He did however acknowledge that the matter was likely to have to be resolved by the ECJ. This approach was followed in JKN V JCN. ${ }^{138}$

Some commentators such as Lord Justice Thorpe ${ }^{139}$ argue that bifurcation and transfer of divorce cases is much more suitable for foreign divorce cases than the English courts applying foreign law or indeed foreign judges applying English law. Bifurcation would allow the English court to grant divorce but to refer the issues of maintenance and property to the country of the chosen matrimonial property regime. Lord Justice Thorpe suggests that an Owusu approach where the UK would not be permitted to give up jurisdiction to decide on maintenance should not be permitted particularly where it is choice between two common law jurisdictions. ${ }^{140}$ However, the bifurcation approach would not work where the other jurisdiction was Ireland which links declaration of divorce and financial obligations.

\section{G. ConClusions}

The envisaged framework for international divorce is becoming unmanageable and this is contrary to the express intent to simplify. This undermines the EU policy goals of certainty for the parties and the ability to exercise informed autonomy.

The characterisation of divorce into the three snapshots of decree, maintenance and matrimonial property ignores the ties between these three events provided by domestic policy. Unless the interaction of the regulations is co-ordinated this could result in the replacement of clear policy with a non-policy - taking the character out of family law. Many commentators have criticised the development of separate fields in family law and argue that one regulation assigning all aspects of divorce to the law of one country would be preferable. ${ }^{141}$

It does seem that the proposed system is better suited to the civil law treatment of divorce than the common law package approach of England and Wales and Ireland. The particular importance of the duty to support after divorce in these countries has not really been properly considered and this shows the lack of consideration of the public nature of marriage.

Although some commentators such as Clarkson ${ }^{142}$ have argued that the UK is ready for Rome IV, the existing case law on Brussels II bis and foreign matrimonial regimes shows that the court is only too willing to put its domestic policy across where there is a connection to England and to wash its hands of a case where a connection is lacking. ${ }^{143}$ An English spouse should not escape the public obligations of marriage nor should a German spouse be held to English obligations when they committed to German ones.

\footnotetext{
137 Cook, supra n135, [10].

${ }^{138}$ [2010] EWHC 843 (Fam).

139 Thorpe "London -- The Divorce Capital of the World" [2009] Fam Law 21.

140 lbid.

${ }^{141}$ Kroll K "Unification of Conflicts of Laws in Europe" in Boele-Woelki and Sverdrup (Ed) European Challenges in Contemporary Family Law (Intersentia 2008) 390; Boele-Woelki Unifying and Harmonizing Substantive Law and Role of Conflicts of Law, (Pocketbooks of the Hague Academy of International Law, Martinus Nijhoff, 2010) [3.1.4]; Boele-Woelki Unifying and Harmonizing Substantive Law and Role of Conflicts of Law, (Pocketbooks of the Hague Academy of International Law, Martinus Nijhoff, 2010) [3.1.4].

${ }^{142}$ Clarkson "Matrimonial Property on Divorce: All Change in Europe" (2008) 22 Journal of Private International Law 421-442.

143 JKN, supra n138, Moore, supra n111.
} 
The conflict with the common law approach occurs because England and Ireland do not recognise different levels of connection to their domestic divorce law. You either have a sufficient connection to be bound completely by their idea of the obligations of marriage as applied to the decree, maintenance and property consequences or you do not. The main reason behind this insistence on domestic law is the fear that domestic law will be usurped and nationals of England and Ireland will be able to avoid the public commitments of marriage. ${ }^{144}$ This can explain why both countries have opted out of Rome III.

However, neither English nor Irish law has really explained what level of connection to the country is necessary to trigger these obligations and this tends to differ case to case and judge to judge. Where a marriage is connected with more than one country the strong public element that English and Irish law assume is there, is not present. It becomes difficult to justify holding parties to English or Irish law, yet similarly difficult to deny them common law levels of ancillary relief. One solution would be for the common law Member States to engage with the European legislative process to a greater degree. Another would be to reform domestic law to make it clear what link to the England and Wales and Ireland is required to engage the financial obligations of marriage.

A lack of consideration of some of the public aspects of marriage is present in the EU regime. It fails to consider certain domestic conservative family law policies such as the continuation of the duty to support after the end of marriage, ${ }^{145}$ the refusal to grant divorce without satisfaction of support and property obligations and the refusal to allow the parties to regulate the property consequences of their marriage without court scrutiny. ${ }^{146}$ Thus international couples can avoid these effects of national law by sharp practice. No doubt many people will welcome this preference for liberal divorce law but its legitimacy must be questioned. Liberal divorce regimes are favoured at an EU level on the basis of mere convenience and certainty without viewing the divorce process as a whole at any point. Further empirical work by the EU is required to study the substantive problems that occur in transnational divorces beyond figuring out what law might potentially be applicable. The work of the European Judicial Network in civil and commercial matters could go some way to helping judges make coherent sense out of the domestic policy goals of different regimes of applicable law.

\footnotetext{
${ }^{144}$ Ireland had particular concerns with the original Brussels II convention and wanted the court of the state in which a claim for recognition was made, to authenticate the existence of a connection with the court which had awarded the judgment. This was a departure from the classic prohibition on review as to substance at the time of recognition of a foreign judgment, enshrined in Article 18 of the Brussels II Convention and Article 29 of the Brussels I Convention. G Shannon, "The Impact and Application of the Brussels II bis Regulation in Ireland" in K Boele-Woelki and C Gonzalez Beilfuss (eds) Brussels II bis: Its Impact and Application in the Member States (Intersentia, Antwerp 2007) 149.

145 Ireland and England.

${ }^{146}$ Ireland and England.
} 